\section{Yo maté a Sherezade. Confesiones de una mujer árabe furiosa}

\author{
Madrid, Editorial Debate \\ Autor: Joumana Haddad
}

Año: 2011

Número de páginas: 144

Por: Edward Javier Ordóñez Iván Enrique Valdez Martínez

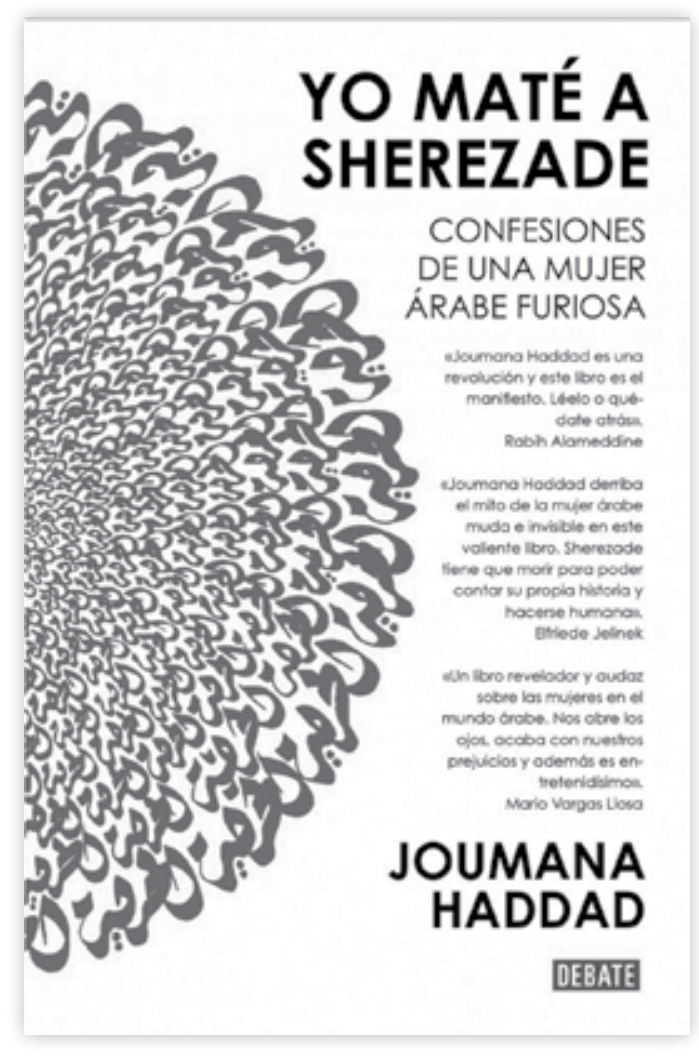

de la situación de la mujer árabe de hoy en día. Sin embargo, el imaginario de la mujer occidental es también duramente cuestionado. Si en Oriente las mujeres cubren su piel y rostro con la burka y el niqab-, en Occidente la piel desnuda genera plusvalía. En otras palabras, Haddad cuestiona los predicamentos acerca de la mujer en la cultura árabe, pero también muestra las debilidades de las culturas occidentales respecto a su situación.

$\mathrm{Al}$ abrir el libro nos encontramos con siete capítulos que dejan ver la forma como Joumana Haddad lucha contra sus demonios y forja su peculiar estilo:

1. "Una mujer árabe que lee al Marqués de Sade" es el punto de inflexión en el que la autora a partir de su propia experiencia (la de una mujer árabe liberal) rompe las cadenas de la opresión al tiempo que depone las ideas occidentales que se tienen acerca de la cultura femenina árabe. Sherezade es el recurso al que apela y postula -al igual que Benjamín, Agamben, Dussel y otros- que la víctima es quien reescri-

EDWARD JAVIER ORDÓÑEZ. Psicólogo y licenciado en Filosofía. Maestro en Filosofía; Doctorando en Estudios Latinoamericanos, UNAM. Correo electrónico: edward.javier11@gmail.com. IVÁN ENRIQUE VALDEZ. Auxiliar de investigación; estudiante de psicología clínica en la Universidad Unimetropolitana de Monterrey. Correo electrónico: ivan_azul_barca@hotmail.com 
be la historia. Joumana Haddad representa esa pequeña parte de las mujeres árabes que han sido capaces de enfrentar radicalmente sobre la base de la evolución y la libertad de pensamiento y de expresión, la tradición oral y el nomos de su propia cultura. En este capítulo Haddad hace referencia a las lecturas que posibilitaron sus nuevos pensamientos acerca de la mujer en la cultura, particularmente en su cultura. Lectora precoz, en la pequeña biblioteca de su padre se sumergió de lleno en libros que la afectaron profundamente, en especial Justine del Marqués de Sade y Las ilusiones perdidas de Balzac. El Marqués de Sade le permitió disfrutar de su sexo, que dejó de ser para ella un tema tabú y comenzó a apropiárselo de manera natural.

2. "Una mujer árabe que no pertenece a ningún sitio" es una pugna con su lugar de origen por la identidad. La violencia no le da motivos para sentirse orgullosa, por tanto rechaza totalmente cualquier tipo de apego o identidad con su lugar de origen. Haddad no le debe nada a su país y no encuentra en él algo para agradecer:

Cuando hoy contemplo Beirut, veo una mujer que ha perdido su identidad, atrapada en el círculo infinito de la cirugía plástica; una mujer que se mira continuamente al espejo en lugar de a su alma intentando recuperar algo de su magia, gracia y gloria pasadas. (pág.49).

También caracteriza de manera contundente a su ciudad natal: "Beirut. Mártir y puta", veredicto que anuncia la sentencia final: "así tal vez mi ciudad verdadera sea, simplemente... ¡yo misma!” (pág. 55).

3. "Una mujer árabe que escribe poesía erótica" es el tercero de los capítulos y en él señala las metáforas que aplicadas a la poesía erótica árabe atentan contra el espíritu humano. La falsa doble moral evita el cuerpo y el sexo; Hadad, por el contrario, se fascina con ellos y los acepta completamente. Ella, liberal, choca con su país ultraconservador que la cataloga como "pervertida" y "depravada".

4. En "Una mujer árabe que crea una revista sobre el cuerpo", Joumana Haddad pone en evidencia la desigualdad sexual en las páginas de su revista, medio que le ha costado ser el blanco de epítetos como pervertida", "inmoral", "falta de escrúpulos" o simplemente "zorra”. En cambio (e injustamente), si un hombre hubiese sido el creador de tal publicación solo se tendrían para él palabras de elogio. El argumento sobre el cual se sustenta la censura es la protección de los valores culturales árabes representados en la Sharía como fuente de toda moral. Sin embargo, para Haddad este código no deja de ser un cuerpo de normas retrogrado y en crisis, que no permite contraargumento alguno a fin de no trastornar el statu quo. Pero la crítica y la censura no hacen más que dar publicidad a lo vetado, le otorga notoriedad y propaga su éxito; y eso es precisamente lo que ha sucedido con su publicación.

5. "Una mujer árabe que redefine su feminidad" permite a la autora realzar su condición femenina y muestra que luchar contra el sistema machista no implica abandonar la condición de mujer (la mujer es significada en su totalidad: bella y realmente inteligente) y la lucha por sus derechos no entraña el abandono de la feminidad. Entonces, ¿qué opina nuestra autora de los hombres? Lo masculino representa un estado de lo femenino comprendido en los conceptos "dependencia" y "necesidad". El primero indica falta de autoestima; el segundo lo acepta como valor y condición fundamental para el desarrollo de la feminidad.

6. En el capítulo sexto "Una mujer que no teme provocar a Alá” -el más controvertido-Hadad critica las religiones cristiana musulmana y pone en tela de juicio los pensamientos religiosos que desde siempre han satanizado las actividades que vayan en contra de su historia y de lo que sus respectivos dioses han dictaminado como leyes que regulan la condición natural humana. El cielo y la vida eterna son promesas y "recompensas" para nada seguras. Las religiones son nocivas para el sentido común, para el modo de vida de cada uno, para la capacidad de decisión individual e incluso para la salud. El cáncer principal de la religión, según Haddad, se encuentra en su incapacidad para guiar a sus creyentes hacia una vida plena.

7. En el séptimo capítulo "Una mujer árabe que vive y dice no", Joumana Haddad nos revela una clara aceptación de su persona así como 
su lado humano errático y rebelde al tiempo que manifiesta su seguro convencimiento de que algún día la situación de las mujeres árabes cambiará.

Finalmente, cabe destacar tres apéndices imposibles de soslayar. En el primero da identidad al sujeto árabe y lo define como un esquizofrénico que no tiene permitido "vivir ni pensar en lo que realmente se quiere vivir", trastorno que desemboca en la prohibición de expresar sentimientos individuales por encima de los del grupo y permite a los "oscurantistas" controlar la falsa "doble moral". El segundo es un replanteamiento de lo que para ella significa ser mujer árabe, pero sobre todo es un reconocimiento a esa pequeña porción de mujeres nativas que han librado su misma batalla. El último, el "Posparto", retoma a Sherezade y la asesina. Ella es un insulto para toda mujer, ya que proclama la dependencia hacia el hombre.
Su muerte elimina todos los estigmas y derriba las barreras para convertirlas en herramientas que coadyuven en la superación femenina.

A manera de cierre, cabe destacar que el libro es un grito coherente e inteligente que visibiliza a la mujer y al lugar desde el que se emite: Beirut. Joumana Haddad ha insertado en su discurso autobiográfico un estudio poscolonial que ahonda en la situación actual, real y metafórica de la mujer árabe. Así, Yo maté a Sherezade. Confesiones de una mujer árabe furiosa, es un libro que deconstruye los arquetipos femeninos y a partir de su autobiografía, de las tensiones políticas y de las controversias por la publicación de una revista que da al cuerpo su máxima expresión, introduce lo que las intelectuales musulmanas contemporáneas de Haddad, a saber, Ayaan Hirsi Ali y Fatema Mernissi anhelan: la "ilustración" del mundo árabe. 